\title{
A HERANÇA KANTIANA DE HANS KELSEN NA TEORIA PURA DO DIREITO
}

\author{
Felipe Rodrigues Xavier
}

\section{RESUMO}

O artigo investiga a influência da enorme herança kantiana na Teoria Pura do Direito de Hans Kelsen, uma das obras mais importantes da teoria jurídica do séc. XX. Partindo da cisão fundamental operada por Kelsen na filosofia kantiana em oposição ao idealismo objetivo hegeliano (a qual o jusfilósofo deve ao ambiente intelectual do neokantismo subdivido entre a Escola de Baden, mais ligada à lógica e à ciência, e a Escola de Marburgo de Hermann Cohen), o trabalho pesquisa a epistemologia da Crítica da Razão Pura e a doutrina ético-moral de Kant contidas na Crítica da Razão Prática, na Metafísica dos costumes e sua Fundamentação, e as consequências de sua adoção ou recusa parciais, principalmente na hermenêutica jurídica, interpretação e aplicação do direito, na doutrina kelseniana.

Palavras-chave: Teoria Pura do Direito. Moral. Imperativo-categórico. Hermenêutica jurídica.

\section{INTRODUÇÃO}

O artigo investiga a conexão entre os pressupostos epistemológicos da Teoria Pura do Direito, dominante na teoria jurídica do séc. XX, e a enorme herança da filosofia kantiana para a modernidade. Tal conexão ou se é deixada em segundo plano ou, principalmente, muitas vezes exagerada pois, de maneira geral, as variadas correntes filosóficas críticas ou reformuladoras de Kant se refletiram em perspectivas que se opuseram igualmente à Teoria Pura kelseniana.

Há uma cisão fundamental operada por Kelsen no âmago da filosofia kantiana, de modo que o jusfilósofo austríaco considera o Kant da Crítica da Razão Pura completamente diverso, senão oposto, ao mesmo Kant da Crítica da Razão Prática. Esta cisão se explica no ambiente intelectual vivenciado por Kelsen do neokantismo subdividido entre Escola de Baden e Escola de

\footnotetext{
${ }^{1}$ Mestre e bacharel em Direito (UNESP). Ex-editor da Revista de Estudos Jurídicos - REJ/UNESP. Atua também nas áreas de Direito Constitucional e Processual Civil. Advogado e Consultor. Professor de Direito. Poeta. Email: felipe.rodrigues.xavier14@gmai.com.
} 
Marburgo, com destaque a Hermann Cohen, sendo esta última as raízes epistemológicas mais próximas de sua grande obra a ponto de Kelsen comparar as batalhas respectivas: da Teoria Pura do Direito contra o direito natural e da Crítica da Razão Pura contra a metafísica.

O artigo se inicia com esta cisão. Posteriormente, nas segunda e terceira partes do artigo, são analisados o imperativo categórico kantiano e as relações e diferenças entre ser e dever ser, elementos essenciais da doutrina ético-moral de Kant que fundamentam, por sua vez, sua doutrina jurídica. Por fim, a tentativa de Kelsen de corte do cordão umbilical entre moral e direito, ou seja, a desconsideração completa acerca de quaisquer elementos morais na compreensão do direito, resulta na aplicação ateorética - e antikantiana - de toda a Teoria Pura, justamente na hermenêutica jurídica, interpretação e aplicação do direito, contida no capítulo VIII. Este o principal objetivo do artigo: demonstrar de que modo a recusa da moral na ciência jurídica causa seu profundo empobrecimento e, paradoxalmente em relação aos cânones positivistas, sua irracionalidade.

\section{OS DOIS KANT PARA KELSEN}

O grande mérito de Immanuel Kant que o faz figurar no panteão dos maiores autores da humanidade é a sua investigação e sistematização de todo o conhecimento humano. Para Kant, a razão origina-se de duas fontes diferentes em dois momentos diferentes, ambas se completando continuamente a formar aquilo a que chamamos conhecimento.

\footnotetext{
Não resta dúvida de que todo o nosso conhecimento começa pela experiência; efetivamente, que outra coisa poderia despertar e pôr em ação a nossa capacidade de conhecer senão os objetos que afetam os sentidos e que, por um lado, originam por si mesmos as representações e, por outro lado, põem em movimento a nossa faculdade intelectual e levam-na a compará-las, ligá-las ou separá-las, transformando assim a matéria bruta das impressões sensíveis num conhecimento que se denomina experiência? Assim, na ordem do tempo, nenhum conhecimento precede em nós a experiência e é com esta que todo o conhecimento tem o seu início. Se, porém, todo o conhecimento se inicia com a experiência, isso não prova que todo ele derive $d a$ experiência. (KANT, 2001, p. 62, grifo do autor).
}

A razão pura, ou razão teórica, é formada por categorias racionais a priori das quais são dotados todos os seres racionais, "“...] um conhecimento assim, independente da experiência e de todas as impressões dos sentidos. Denomina-se a priori esse conhecimento e distingue-se do empírico, cuja origem é a posteriori, ou seja, na experiência.” (KANT, 2001, p. 63, grifo do autor). 
A razão pura independe de fins. A razão pura apenas conhece, se expressando em relações racionais necessárias. Como os maiores exemplos, o espaço e o tempo. "Por uma crítica assim, não entendo uma crítica de livros e de sistemas, mas da faculdade da razão em geral, com respeito a todos os conhecimentos a que pode aspirar, independentemente de toda a experiência." (KANT, 2001, p. 31-32, grifo do autor).

A razão prática é formada pela experiência a posteriori; experiência esta, por sua vez, moldada por aquelas categorias puras a priori. A razão prática objetiva fins. A razão prática quer, se expressando em relações de obrigatoriedade.

Da razão prática, ou vontade em sentido amplo, utilizadas como sinônimos a partir de agora, derivam tanto o imperativo categórico como a vontade em sentido estrito. A razão prática é razão que age, é razão fundamento da ação ao conferir significado a si mesma e aos objetos da vontade, e isto em suas duas derivações. É dela que se origina a noção de dever ser.

Neste ponto poderia surgir o questionamento se a doutrina de Kant não seria mais outra reformulação da tradição platônica, a cisão entre teoria e prática e o mundo da caverna. Há diferenças essenciais. $\mathrm{O}$ dever ser platônico está no mundo das ideias, padrão para o conhecimento. O dever ser kantiano encontra-se na consciência humana, é a própria lei moral a priori da racionalidade, padrão para o agir. A razão prática de Kant age, a razão prática é vontade que possui finalidades, ou seja, objetiva modificar o mundo.

Eis a cisão das filosofias antiga e medieval para a moderna. Por isto o criticismo kantiano, por isto suas principais obras são Críticas. À cisão filosófica corresponde a cisão de mundo entre Idade Média e Modernidade, entre o absoluto e a consciência ${ }^{2}$, cuja primeira revelação se dá ainda antes de Kant com o Hamlet de Shakespeare.

$V_{\text {Vontade }}^{3}$, ou o âmago de toda a doutrina kantiana da ética (em sentido amplo, abarcando moral e direito), é a capacidade racional, “[...] só um ser racional tem a capacidade de agir segundo a representação das leis, isto é, segundo princípios, ou: só ele tem uma vontade." (KANT, 2007,

\footnotetext{
${ }^{2} \mathrm{O}$ imperativo categórico, máximo critério da moralidade, independe da religião, da ciência, da política, etc., residindo na consciência humana. O homem como centro do universo.

${ }^{3}$ Vontade que também origina o contrato social. Veja-se a conceituação de Kant através dos conceito de liberdade (exterior, jurídica e obrigacional) e de vontade: "Há que se explicar minha liberdade exterior (jurídica) como sendo a faculdade de não obedecer a nenhuma lei exterior a não ser que tenha dado eu o consentimento. Desta forma, $a$ igualdade exterior (jurídica) em um Estado consiste na relação entre os cidadãos segundo a qual ninguém pode impor ao outro uma obrigação jurídica sem submeter-se, ele mesmo, também a esta e poder ser, da mesma maneira, obrigado." (KANT, 2006, p. 67, grifo nosso).
} 
p. 47, grifo nosso). Na Fundamentação da metafísica dos costumes ${ }^{4}$, ou Crítica da razão pura prática, Kant (2007, p. 47) a define como a própria razão prática: como não possui fundamento determinante, a vontade é ela mesma fundamento das ações, a razão que faz derivar as ações das leis morais.

\begin{abstract}
Uma ação praticada por dever tem o seu valor moral, não no propósito que com ela se quer atingir, mas na máxima que a determina; não depende portanto da realidade do objeto da ação, mas somente do princípio do querer segundo o qual a ação, abstraindo de todos os objetos da faculdade de desejar, foi praticada. Que os propósitos que possamos ter ao praticar certas ações e os seus efeitos, como fins e móbiles da vontade, não podem dar às ações nenhum valor incondicionado, nenhum valor moral, resulta claramente do que fica atrás. (KANT, 2007, p. 30, grifo nosso).
\end{abstract}

O próprio Kelsen afirma a fundamentação da Teoria Pura do Direito na epistemologia da Crítica da razão pura e a completa recusa, justificada na alegação de quebra de fidelidade, da doutrina moral e ética de Kant (contidas Crítica da razão prática, na Metafísica dos costumes e sua Fundamentação, principalmente):

É absolutamente verdadeiro que o fundamento filosófico da Teoria Pura do Direito se assenta na filosofia kantiana ou, mais precisamente, na interpretação coheniana dessa filosofia. [...] Assim como a filosofia transcendental de Kant se erige contra a metafísica, a Teoria Pura do Direito se erige contra o direito natural, este sendo o correspondente exato, no domínio da realidade social, em geral, e do direito positivo em particular, da metafísica. [...] Na medida que a Teoria Pura do Direito tentou, de maneira totalmente inédita, apresentar a filosofia de Kant como uma teoria do direito positivo (em oposição a Stammler, ainda muito ligado à teoria do direito natural) ela foi, em um certo sentido, além do pensamento de Kant que, em sua doutrina do direito, abandona o método transcendental. (KELSEN apud MATOS, 2004, p. 38, grifo nosso).

Cohen é neokantiano da Escola de Marburgo. A fundamentação da Teoria Pura limita-se, quanto à doutrina kantiana, na filosofia transcendental, mas não transcendente, da Crítica da razão pura (os conceitos e categorias a priori, totalmente reformulados na Teoria Pura). Kelsen reafirma o paralelo de objetivos entre a Teoria Pura, de combate contra o direito natural, e a Crítica da razão pura contra a metafísica.

\footnotetext{
4 "Pode-se chamar empírica a toda a filosofia que se baseie em princípios da experiência, àquela, porém cujas doutrinas se apoiam em princípios a priori chama-se filosofia pura. Esta última, quando é simplesmente formal, chama-se Lógica; mas quando se limita a determinados objetos do entendimento chama-se Metafísica. Desta maneira surge a ideia duma dupla metafísica, uma Metafísica da Natureza e uma Metafísica dos Costumes.” (KANT, 2007, p. 14). Ou seja, filosofia empírica é a baseada na experiência, a posteriori, enquanto filosofia pura é a fundamentada nos princípios a priori. A filosofia pura divide-se em formal (Lógica) ou limitada a algum âmbito da racionalidade pelo qual recebe seu nome (Metafísica da Natureza e Metafísica dos Costumes).
} 
No entanto, o paralelo termina aí. Kelsen não deve a Kant muito mais do que qualquer outro pensador da modernidade, se considerarmos Kant o principal "artífice filosófico" deste período. Isto porque Kelsen acredita que há uma ruptura entre as doutrinas kantianas epistemológica, de um lado, e a moral e jurídica, do outro, tendo nestas últimas Kant renunciado ao método transcendental. Por conseguinte, para Kelsen, neste âmbito a doutrina de Kant é somente outra metafísica.

Ora, aqui a concepção de metafísica torna-se decisiva:

Para Kant, por "metafísica" entende-se a filosofia pura a priori, independente da experiência e da vontade, limitada a algum objeto do entendimento humano. Desta forma, há tantas "metafísicas" quanto os objetos da filosofia pura, exemplificando-se com a Metafísica da Natureza e a Metafísica dos Costumes (KANT, 2007, p. 14).

Para Kelsen, por "metafísico" entende-se tudo o que não pode ser medido em algum padrão calculável, tudo o que não pode ser demonstrado. Kelsen é, antes de tudo, cientificamente positivista, e no estrito positivismo científico não lhe são admissíveis os conceitos a priori bem como a vontade da filosofia de Kant. Não lhe sendo compreensíveis, resta a Kelsen somente inabilitá-los como metafísicos, acusando Kant de incorrer nas mesmas falhas dos jusnaturalistas.

A partir desta diferenciação, torna-se possível verificar alguns erros na interpretação kelseniana de Kant.

Pois bem,

A filosofia moral 'aplicada ao homem, não vai buscar, o mínimo que seja, ao conhecimento
do mesmo homem (antropologia), mas dita-lhe, enquanto ser racional, leis a priori'. O
conhecimento da razão designado como ética ou filosofia moral é legiferante. A ética e a
moral, o conhecimento e o seu objeto são, assim, identificados. É esta a consequência do
conceito de razão prática. Tal consequência revela-se bem no fato de Kant, assim como
identifica a ética com a moral, identifica a ciência jurídica com o direito. Diz ele: 'O conjunto
das leis para as quais é possível uma legislação externa chama-se teoria do direito (ius). Se uma
tal legislação é efetiva (wirklich), aquela será uma teoria do direito positivo'. (KELSEN, 2001,
p. 128, grifo nosso).

Ora, “ética” e "moral” não são identificadas, não totalmente. Isto está claríssimo em Kant, sendo "ética" (em sentido amplo) o conjunto de normas morais que abarcam tanto a doutrina da "moral" (em sentido estrito) como do direito. Os termos "ética" e "moral” não são sinônimos como faz pretender Kelsen. Aliás, da primeira frase grifada acima ("o conhecimento da razão designado como ética ou filosofia moral é legiferante") não decorre a segunda ("a ética e a moral, o conhecimento e o seu objeto são, assim, identificados"). Nem tampouco na doutrina kantiana "ética" refere-se à ciência e "moral" ao conteúdo. Trata-se da organização aristotélica. 
Do mesmo modo, o conceito kantiano de vontade:

Para poder atribuir à vontade a 'liberdade' da razão frente aos seus juízos, ou seja, portanto, a liberdade da razão cognoscente, Kant tem de identificar à vontade com a razão. A razão identificada com a vontade é a razão prática. Kant acentua repetidas vezes que a razão prática é vontade. Diz ele: 'A vontade não é senão razão prática'. Ele equipara a 'razão prática' à 'vontade' aditando à expressão 'razão prática', entre parêntesis, a palavra 'vontade'. E somente porque vê na razão prática a vontade é que ele pode figurar esta razão como legisladora. (KELSEN, 2001, p. 124).

Quanto à razão prática ser vontade não há dúvidas. No entanto, a razão não é prática, somente ou, em outras palavras, a razão não é apenas vontade. Kant não limitou-se à Crítica da razão prática, deixando bastante claro que a razão é una: a enorme tarefa de investigar como se dá a entendimento humano não poderia ser realizada sem alguma organização dos tópicos, alguma organização teóricoracional das principais fontes do entendimento humano que para Kant, como é óbvio, são a razão pura e a razão prática, ambas estando umbilicalmente ligadas ou sendo, de fato, a Razão una, “[...] pois no fim das contas trata-se sempre de uma só e mesma razão, que só na aplicação se deve diferenciar." (KANT, 2003, p. 18, grifo nosso).

Vontade de todo o ser racional concebida como vontade legisladora universal. Segundo este princípio são rejeitadas todas as máximas que não possam subsistir juntamente com a própria legislação universal da vontade. A vontade não está pois simplesmente submetida à lei, mas sim submetida de tal maneira que tem de ser considerada também como legisladora ela mesma. (KANT, 2007, p. 72, grifo do autor).

Da citação acima depreende-se que tanto a vontade como a lei moral são fundamentos da ação e, deste modo, consideradas legisladoras universais porque pertencentes a todo ser racional. A "legislação" aqui diz respeito ao âmbito moral e racional mais primário do ser humano e não, logicamente, à questão jurídica a qual, por sua vez, deriva de ambas. Inclusive, entre as duas, a vontade encontra-se submetida à lei moral e o imperativo categórico não é nada mais, nada menos, que o critério para se saber se esta vontade está contida ou se pode se tornar ela mesma a própria lei moral.

Kelsen omite ou altera decisivamente questões essenciais da doutrina kantiana, chegando ao extremo de acusar a razão prática (vontade) de teológica-religiosa ${ }^{5}$. Os evidentes equívocos

\footnotetext{
5 “A normação, a legislação, não é, porém, uma função do conhecimento. Com a fixação de uma norma não se conhece um objeto já dado, tal como ele é, mas exige-se algo que deve ser. Neste sentido, a normação é uma função do querer, não do conhecer. Uma razão normadora é ao mesmo tempo uma razão cognoscitiva e querente, é, simultaneamente, conhecer e querer. Estamos em face do conceito em si contraditório de razão prática, que desempenha um papel decisivo não só na teoria do direito natural concebida como teoria do direito racional, mas ainda na ética. Este conceito de razão prática é de origem teológico-religiosa." (KELSEN, 2001, p. 116, grifo nosso).
} 
interpretativos de Kelsen sobre Kant em pontos essenciais (o que são "ética" e "moral" e suas relações, bem como a razão prática e a vontade) interferem radicalmente na Teoria Pura do Direito e na ciência jurídica desde então.

\section{O IMPERATIVO CATEGÓRICO}

O imperativo ${ }^{6}$ categórico ${ }^{7}$, dentre algumas versões, "Age apenas segundo uma máxima tal que possas ao mesmo tempo querer que ela se torne lei universal." (KANT, 2007, p. 59), é o princípio fundamental da doutrina moral (e jurídica) de Kant. O imperativo categórico pressupõe conhecimentos inatos e a priori da racionalidade, independentes da experiência e da vontade ${ }^{8}$. A partir deles o ser racional homem torna-se capaz de compreender se a própria ação pode ser estendida objetivamente a todos os seres racionais como norma moral válida 9 .

O imperativo categórico, portanto, é o critério fundamental, a medida maior, o teste, enfim, que toda ação racional tem de passar para se saber moralmente boa ou moralmente má.

A lei moral, segundo Kant, é de per si evidente a qualquer ser racional, o que em verdade o caracteriza como racional. Portanto, as faculdades racionais inatas ao homem tornam-no capaz,

\footnotetext{
6 “A representação de um princípio objetivo, enquanto obrigante para uma vontade, chama-se um mandamento (da razão), e a fórmula do mandamento chama-se imperativo. Todos os imperativos se exprimem pelo verbo dever (sollen), e mostram assim a relação de uma lei objetiva da razão para uma vontade." (KANT, 2007, p. 48).

7 "Ora, todos os imperativos ordenam ou hipotética ou categoricamente. Os hipotéticos representam a necessidade prática de uma ação possível como meio de alcançar qualquer outra coisa que se quer (ou que é possível que se queira). O imperativo categórico seria aquele que nos representasse uma ação como objetivamente necessária por si mesma, sem relação com qualquer outra finalidade. [...] No caso de a ação ser apenas boa como meio para qualquer outra coisa, o imperativo é hipotético; se a ação é representada como boa em si, por conseguinte como necessária numa vontade em si conforme à razão como princípio dessa vontade, então o imperativo é categórico [...] O imperativo hipotético diz pois apenas que a ação é boa em vista de qualquer intenção possível ou real. No primeiro caso é um princípio problemático, no segundo um princípio assertórico-prático. O imperativo categórico, que declara a ação como objetivamente necessária por si, independentemente de qualquer intenção, quer dizer sem qualquer outra finalidade, vale como princípio apodítico (prático).” (KANT, 2007, p. 50-51).

8 "Mas que lei pode ser então essa, cuja representação, mesmo sem tomar em consideração o efeito que dela se espera, tem de determinar à vontade para que esta se possa chamar boa absolutamente e sem restrição? Uma vez que despojei a vontade de todos os estímulos que lhe poderiam advir da obediência a qualquer lei, nada mais resta do que a conformidade a uma lei universal das ações em geral que possa servir de único princípio à vontade, isto é: devo proceder sempre de maneira que eu possa querer também que a minha máxima se torne uma lei universal." (KANT, 2007, p. 33, grifo nosso). "O imperativo é categórico. Não se relaciona com a matéria da ação e com o que dela deve resultar, mas com a forma e o princípio de que ela mesma deriva [...] este imperativo pode-se chamar o imperativo da moralidade." (KANT, 2007, p. 52, grifo nosso).

9 "Podes tu querer também que a tua máxima se converta em lei universal? Se não podes, então deves rejeitá-la, e não por causa de qualquer prejuízo que dela pudesse resultar para ti ou para os outros, mas porque ela não pode caber como princípio numa possível legislação universal.” (KANT, 2007, p. 35).
} 
independentemente de sua vontade, de compreender quando sua máxima torna-se possível de se transformar em lei universal ${ }^{10}$.

Pois bem, Hans Kelsen afasta a possibilidade desta lei moral a priori, padrão supremo tanto para a ética como para o direito e a vontade, como metafísica. Kelsen relativiza esta lei moral. "Mas, de que máxima devo eu querer e de que máxima devo eu não querer que ela se torne numa lei universal? A esta questão não dá o imperativo categórico qualquer resposta.” (KELSEN, 2001, p. 61). A pressuposição fundamental de Kelsen a partir da qual ele altera o imperativo categórico de lei moral para fórmula de vontade, pedra de toque para todas as críticas e refutação da doutrina moral e jurídica de Kant, é esta:

Se, efetivamente, como parece ser o caso, segundo a fórmula citada, se tratasse de saber se nós podemos querer que aquilo que nos propomos a nós próprios como regra do nosso agir se transforme numa lei universal, então o imperativo categórico não conduziria necessariamente a uma atuação moralmente boa. Com efeito, um homem pode de fato querer de toda e qualquer máxima que ela se transforme numa lei universal. (KELSEN, 1998, p. 21-22).

Em Kelsen ${ }^{11}$, o imperativo categórico transmuta-se de máximo dever moral de adequação para vontade, utilizando-se para tanto duma versão do imperativo categórico do próprio Kant ligeiramente modificada: "Age como se a máxima da tua ação se devesse tornar, pela tua vontade, em lei universal da natureza." (KANT, 2007, p. 59, grifo do autor). “É, assim, patente que, com o 'poder querer' do imperativo categórico, se quer significar um 'dever querer', que o verdadeiro sentido do imperativo categórico é: 'atua segundo uma máxima da qual devas querer que ela se transforme numa lei universal. "’ (KELSEN, 1998, p. 26, grifo nosso).

Segundo Kelsen, o imperativo categórico como fórmula racional sofre da mesma incapacidade destas outras fórmulas: a de ser uma espécie de lacuna preenchida contingencialmente por qualquer solução imaginável, não deduzível da generalidade da fórmula

\footnotetext{
10 “Máxima é o princípio subjetivo da ação e tem de se distinguir do princípio objetivo, quer dizer da lei prática. Aquela contém a regra prática que determina a razão em conformidade com as condições do sujeito (muitas vezes em conformidade com a sua ignorância ou as suas inclinações), e é portanto o princípio segundo o qual o sujeito age; a lei, porém, é o princípio objetivo, válido para todo o ser racional, princípio segundo o qual ele deve agir, quer dizer um imperativo." (KANT, 2007, p. 58, grifo do autor).

11 "Este imperativo (categórico) não é propriamente pensado como uma norma de justiça, mas como um princípio geral e supremo da moral no qual está contido o princípio da justiça.” (KELSEN, 2001, p. 56), o que acaba por resultar na mesma consequência: o imperativo categórico é o critério supremo da moralidade racional para julgar as condutas humanas, inclusive as que lidarem com a justiça como a atividade legislativa, por exemplo.
} 
categórica, e que geralmente, se não invariavelmente, conduz a algum valor absoluto ${ }^{12}$ de pessoas, grupos e sociedades concretas disfarçado sob aquela forma universal.

Contudo, a questão decisiva para qualquer ética, a questão de saber qual seja o conteúdo da lei universal com a qual a máxima deve conformar-se, permanece par responder. Também do imperativo que manda agir de acordo com uma lei universal cujo conteúdo não é indicado não se pode deduzir qualquer norma moral que prescreva uma determinada conduta. (KELSEN, 2001, p. 61, grifo nosso).

O imperativo categórico não qualifica as máximas, quais são boas e quais são más. Neste sentido, nada obstaria ao suicida ou ao egoísta dos exemplos kantianos de elevarem sua máxima de suicídio ou egoísmo como lei universal.

A interpretação kelseniana do imperativo categórico apenas se torna possível com a eliminação do elemento a priori da lei moral.

Sem ela, a lei moral ${ }^{13}$, só lhe resta o relativismo filosófico:

À luz da teoria do conhecimento de Kant (a que ele claramente não se mantém fiel na sua ética), mandaria a coerência dizer que uma ciência da moral de forma alguma pode responder a esta questão ( o que é bom e o que é mau), que aquela só pode determinar sob que condição ou pressuposto lógico são possíveis os juízos de que algo é bom ou mau, e que tal condição é: pressuporem-se como válidas normas gerais que prescrevem uma determinada conduta humana. (KELSEN, 1998, p. 28, grifo nosso).

Kelsen acusa Kant de não ter se mantido fiel à teoria do conhecimento na sua doutrina ética (que engloba a moral, direito e o imperativo categórico), e por isto a recusa.

\section{SER E DEVER SER}

A distinção entre ser e dever ser também se encontra em Kelsen, embora completamente modificada. Kelsen pretende, assim como na separação entre ciência e política, erigir em absoluto as categorias do ser (Sein) e do dever ser (Sollen), dogmatizando a cisão como condição mesma

\footnotetext{
${ }^{12} \mathrm{O}$ termo "lacuna" foi propositadamente escolhido para relacionar esta questão moral com a questão dogmática das lacunas do direito positivo, onde Kelsen assume a posição exatamente oposta de inexistência das lacunas. contradição?

13 "Kant crê poder demonstrar que não podemos querer que muitas máximas se transformem em lei universal, procurando mostrar que a vontade de elevar a uma lei universal uma máxima imoral, ou seja, uma máxima que Kant de antemão pressupõe como imoral, ou a lei a que esta máxima e elevada, 'se contradiria a si própria'." (KELSEN, 2001, p. 57). Portanto, sem esta lei moral anterior e suprema, qualquer máxima, mesmo se imoral, não teria com o que se contradizer, podendo se elevar como lei universal.
} 
para a ciência jurídica normativista. Ora, no normativismo o dever ser é simplesmente normativo, referindo-se às normas como objeto específico da ciência jurídica. Despido da qualidade de fundamentação da própria ética (em sentido amplo, englobando moral e direito) a priori, caráter ininteligível ao positivismo de Kelsen e por este motivo repetidamente rejeitado, o dever ser normativo assume o perfil lógico-formal tão identificado com o normativismo kelseniano.

A Teoria Pura do Direito, como específica ciência do Direito, concentra - como já se mostrou - a sua visualização sobre as normas jurídicas e não sobre os fatos da ordem do ser, quer dizer: não a dirige para o querer ou para o representar das normas jurídicas, mas para as normas jurídicas como conteúdo de sentido - querido ou representado. Ela abrange e apreende quaisquer fatos apenas na medida em que são conteúdo de normas jurídicas, quer dizer, na medida em que são determinados por normas jurídicas. O seu problema é a específica legalidade autônoma de uma esfera de sentido. (KELSEN, 2009, p. 113-114, grifo nosso).

Ou seja, a Teoria Pura tem por objeto único e exclusivo o dever ser normativo compreendido como norma.

Assim fenomena e noumena, os reinos do ser e dever ser, respectivamente, são completamente abandonados. Como já analisado, enquanto o ser kantiano refere-se antes à razão pura a priori, ou categorias inatas à racionalidade independentes da experiência e da vontade, o dever ser, por sua vez, trata da razão prática como gênero ético que fundamenta moralmente as ações humanas, dela derivando as espécies moral e direito.

A separação decisiva entre Kant e Kelsen neste aspecto dá-se no dever ser. Como explícito na citação de Kelsen colacionada acima, para o normativista austríaco o dever ser é apenas jurídico, não fundamentando nada a não ser normas. Enquanto nesta concepção muito mais estreita o dever ser é um ato de poder (do legislador ou do juiz, mas não da ciência jurídica) que impõe a norma, o dever ser kantiano, ao invés, é dado racionalmente a priori e oferece a obrigatoriedade "ética" ("normatividade" em sentido amplo) das normas morais e jurídicas, também fundamentando eticamente as ações humanas. A única semelhança restante entre a doutrina de ambos é a localização do direito no âmbito do dever ser (noumena).

Kelsen exemplifica suas noções de ser e dever ser por meio da sociologia e da ciência jurídicas, ao rebater as críticas sobre a impossibilidade de uma ciência normativa do dever ser como “ilusão ideológica”, não sendo, portanto, mais que outra forma de sociologia jurídica disfarçada:

A sociologia do Direito não põe os fatos da ordem do ser cujo conhecimento lhe compete em relação com normas válidas, mas põe-nos em relação com outros fatos da ordem do ser, como causas e efeitos. Ela pergunta, por exemplo, por que causas foi determinado um 
legislador a editar precisamente estas normas e não outras, e que efeitos tiveram os seus comandos. Pergunta por que forma os fatos econômicos e as representações religiosas influenciam, de fato, a atividade do legislador e dos tribunais, por que motivos os indivíduos adaptam ou não a sua conduta à ordem jurídica. Assim, não é, a bem dizer, o próprio Direito que forma o objeto deste conhecimento: são-no antes certos fenômenos paralelos da natureza ${ }^{14}$. (KELSEN, 2009, p. 113, grifo nosso).

Segundo Larenz, "a mais importante objeção que tem de consentir a Teoria Pura do Direito é a de que Kelsen não consegue manter 'a disparidade absoluta entre ser e dever ser'.” (LARENZ, 1997, p. 98, grifo nosso). A objeção mostra toda a sua força em dois momentos decisivos da Teoria Pura. Primeiramente, na norma hipotética fundamental, o dever ser lógico, a qual possui relações de interdependência para com o ordenamento jurídico, o ser. Deste modo, enquanto o ordenamento tem como fundamentação lógica-formal a norma hipotética, esta, por sua vez, sem o ordenamento jurídico é despojada de qualquer função. Em segundo lugar, e mais importante, ser e dever ser destroem-se mutuamente no momento crucial da aplicação do direito pois a decisão independe do dever ser normativo.

Ainda segundo Larenz (1997, p. 98), a objeção da não separação absoluta entre ser e dever ser nunca foi refutada por Kelsen, chegando a colacionar autores que não encontram na obra do normativista austríaco nenhuma definição da expressão “dever ser”, enquanto outros constatam nada mais, nada menos, que dezoito definições (LARENZ, 1997, p. 100).

Em realidade, Kelsen não discorre duas linhas sobre o significado filosófico de "dever ser" utilizado na Teoria Pura; significação que teria de ir forçosamente para além do conceito kelseniano de norma. Afirma ser tão óbvio que não necessita de nenhuma explanação ${ }^{15}$ já que nos é "dada imediatamente à nossa consciência. Ninguém pode negar que daquilo que é não pode concluir-se aquilo que deve ser, assim como daquilo que deve ser não pode concluir-se aquilo que é." (KELSEN apud LARENZ, 1997, p. 94), o que se aproxima demais, se é que não se confunde aqui, com as categorias do conhecimento a priori de Kant tantas vezes rejeitadas como "metafísicas".

\footnotetext{
14 “'A ‘teoria pura do Direito' apreende, pois, o conteúdo jurídico do sentido de um certo evento - que, como tal, é 'um fragmento da natureza', portanto, 'determinado por leis causais' -, ao subsumi-lo a uma norma jurídica que retira a sua validade de ter sido 'produzida' de acordo com outra norma situada acima daquela. Em compensação, a 'teoria pura do Direito' abandona o aspecto fático desse acontecer - por exemplo, os intuitos e os motivos do legislador, bem como os efeitos da regulamentação que estabelece - a outra ciência, que é a sociologia do Direito como 'ciência de fatos'. O que cai sob a alçada desta última não é verdadeiramente o próprio Direito, mas sim, certos fenómenos paralelos da natureza'." (LARENZ, 1997, p. 95).

15 "A distinção entre ser e dever ser não pode ser mais aprofundada. É um dado imediato da nossa consciência." (KELSEN, 2009, p. 6).
} 


\title{
5 JUSTIÇA E MORAL: O PROBLEMA DA INTERPRETAÇÃO
}

A separação entre moral e direito obedece A duas exigências.

A exigência metodológica trata da separação entre direito e ciência do direito. Ora, a ciência do direito é qualificada como tal por ter seu objeto específico, a norma, e metodologia própria, a teoria pura com a qual Kelsen pretende dotá-la. Ciência do Direito e a Teoria Pura do Direito se confundem. Outros elementos que sem dúvida e segundo o próprio Kelsen são essenciais para a compreensão do fenômeno jurídico, como moral e justiça, são deslocados da ciência para o que ele chama de política jurídica, numa consequência direta da opção epistemológica de absoluta separação entre ciência e política.

A exigência filosófica diz respeito à compatibilização entre o positivismo jurídico e o relativismo filosófico, refutando-se no direito qualquer padrão normativo de justiça (que dê significado às normas positivas) por haver uma multiplicidade de conceitos, ideais ou valores de justiça, nenhum melhor ou mais importante que qualquer outro.

Portanto, o fundamento de validade das normas positivadas não é, ou não deve ser, a identificação com normas de justiça, mas segundo critérios formais de produção normativa da própria ordem jurídica. "A exigência de uma separação entre Direito e Moral, Direito e Justiça, significa que a validade de uma ordem jurídica positiva é independente desta Moral absoluta, única válida, da Moral por excelência, de $a$ Moral." (KELSEN, 2009, p. 75, grifo do autor). Neste passo, Hans Kelsen é indiscutivelmente representante do positivismo jurídico exclusivo.

\begin{abstract}
A necessidade de distinguir o Direito da Moral e a ciência jurídica da Ética significa que, do ponto de vista de um conhecimento científico do Direito positivo, a legitimação deste por uma ordem moral distinta da ordem jurídica é irrelevante, pois a ciência jurídica não tem de aprovar ou desaprovar o seu objeto, mas apenas tem de o conhecer e descrever [...] a tarefa da ciência jurídica não é de forma alguma uma valoração ou apreciação do seu objeto, mas uma descrição do mesmo alheia a valores (wertfreie). O jurista científico não se identifica com qualquer valor, nem mesmo como valor jurídico por ele descrito. (KELSEN, 2009, p. 77, grifo nosso).
\end{abstract}

Assim, à relação entre moral e direito correspondem aproximadamente 10 páginas de cerca de 400 da edição definitiva da Teoria Pura.

Moral e direito, na ciência jurídica, são completamente apartadas e independentes. Isto significa que a validade da norma jurídica está na própria ordem jurídica e não na ordem moral; do 
mesmo modo, a norma moral não deixa de ser válida no âmbito moral por não ser ou não estar refletida na ordem jurídica.

Uma moral, uma justiça sendo impossível a demonstração de todos os valores de moral e justiça, bem como a definição dum critério de preferência de determinado valor, como defende o relativismo filosófico, apenas resta ao teórico e aplicador do direito o afastamento de qualquer consideração sobre a moral e a justiça em seu ofício, renunciando a qualquer racionalidade jurídica que as integre.

O relativismo filosófico causa a mesma consequência da moral para a justiça.

\begin{abstract}
A rejeição radical de Kelsen de qualquer teoria da justiça se situa, de maneira singular, na tradição de um filósofo que conhece um conceito moral de direito (natural) e o desenvolve com detalhes: Kant. Mas Kelsen é marcado por aquela tradição do neokantismo cujo pathos científico não tem mais lugar para o conceito de direito (natural) moral de Kant. Esta tradição só reconhece mais, da obra de Kant, a validade da crítica da razão especulativa e não mais da crítica da razão prática. Além disso, esta tradição vê a primeira crítica da razão apenas como teoria do conhecimento e fundamentação de ciências positivas e não [...] como uma preparação suplementar da crítica da razão prática. (HOFFE, 2005, p. 99).
\end{abstract}

A validade da norma jurídica independe de seu conteúdo e, especialmente, da justiça ou injustiça deste conteúdo, de compatibilidade dele com qualquer conceito ou ideal de justiça. Neste ponto não há ruptura com a ciência jurídica anterior: de fato, o enfraquecimento da dicotomia entre "justiça” e "direito ocorre com as codificações do século XIX e a ciência jurídica que lhe seguiu. Kelsen apenas reafirma esta ruptura segundo a sua própria doutrina ${ }^{16}$.

No direito, a questão da justiça é deslocada de qualidade da norma jurídica para qualidade “do ato pelo qual ela é posta, do ato de que ela é o respectivo sentido." (KELSEN, 2001, p. 45; KELSEN, 1998, p. 9). Ora, o "ato pelo qual a norma é posta" é totalmente irrelevante para a Teoria Pura do Direito, foge aos seus limites autotraçados, já que ela trata apenas da norma em si. A questão do "ato" é de política jurídica.

Em síntese,

\footnotetext{
${ }^{16}$ Inclusive, para tanto, Kelsen mais uma vez repele a doutrina moral e jurídica de Kant. Tanto a questão da justiça importava no pensamento do filósofo que afinal propôs fórmulas para ações e leis serem consideradas justas. Enuncia assim o princípio fundamental do direito público: "São injustas todas as ações que se referem ao Direito de outros homens cujos princípios não suportam a publicação'. Não é necessário considerar este princípio como um mero princípio ético (pertencente à doutrina da virtude), mas faz-se mister considerá-lo também como um princípio jurídico (que afeta o Direito dos homens)." (KANT, 2006, p. 110, grifo nosso). Revelando o iluminismo de sua doutrina jurídica, faz depender a justiça da publicidade do direito. Outro princípio do direito público, transcendental e positivo: “'Toda as máximas que necessitam a publicidade (para não fracassar em seus propósitos) concordam com o Direito e a Política ao mesmo tempo'." (KANT, 2006, p. 115).
} 
Uma teoria do direito positivista, isto é, realista, não afirma - e isto importa acentuar sempre - que não haja qualquer justiça, mas que de fato se pressupõem muitas normas de justiça, diferentes umas das outras e possivelmente contraditórias entre si. Ela não nega que a elaboração de uma ordem jurídica positiva possa ser determinada - e em regra, o é de fato - pela representação de qualquer das muitas noções de justiça. Especialmente, não nega que toda ordem jurídica positiva - quer dizer, os atos através dos quais as suas normas são postas - pode ser apreciada ou valorada segundo uma destas formas de justiça, como justa ou injusta [...] Uma teoria jurídica positivista não reconhece o fundamento de validade de uma ordem jurídica positiva em qualquer das muitas normas de justiça, pois não pode dar a qualquer delas preferência sobre as demais. (KELSEN, 2001, p. 101, grifo nosso).

Quase toda a ciência jurídica desde então se constitui em variadas tentativas que procuram, cada uma a seu modo, a racionalização da produção e do discurso jurídicos aliada principalmente à justificação moral das opções jurídico-políticas.

A operação realizada por Kelsen para a retirada do cordão umbilical do direito à moral resulta na aplicação ateorética do direito. O capítulo oitavo consagrado à hermenêutica jurídica nos deixa sem resposta alguma sobre como o aplicador procede ou deveria proceder para a solução hermenêutica do direito. Não há qualquer fundamentação para o saber hermenêutico do direito ${ }^{17}$, enorme lacuna da Teoria Pura, a sua herança maldita, não obstante passar desapercebida pela maior parte da ciência jurídica nacional.

No momento mais importante e decisivo, aquele da interpretação do direito, Kelsen admite abertamente a irracionalidade, independente de qualquer lastro moral ou mesmo jurídico, ao admitir a possibilidade de aplicação da norma jurídica fora de suas possibilidades normativas contidas na moldura.

Importa notar que, pela via da interpretação autêntica, quer dizer, da interpretação de uma norma pelo órgão jurídico que a tem de aplicar, não somente se realiza uma das possibilidades reveladas pela interpretação cognoscitiva da mesma norma, como também se pode produzir uma norma que se situe completamente fora da moldura que a norma a aplicar representa. (KELSEN, 2009, p. 394, grifo nosso).

A constatação revela-se de suma importância. A licença para a aplicação duma possibilidade normativa exterior à moldura é, juridicamente, ilimitada. Trata-se, sem dúvidas, duma "carta branca" dada ao intérprete autêntico sem as fronteiras esboçadas pela moldura

\footnotetext{
17 "Kelsen frustra um dos objetivos fundamentais do saber dogmático [...] sua produção teórica fica sem fundamento, aparecendo como mero arbítrio. Não teria, pois, realmente nenhum valor racional procurar um fundamento teórico para a atividade metódica da doutrina, quando esta busca e atinge o sentido unívoco das palavras da lei? Seria um contrassenso falar em verdade hermenêutica? Enfrentar essa questão constitui o que chamaríamos, então, de o desafio kelseniano." (FERRAZ JUNIOR, 2008, p. 230, grifo nosso).
} 
normativa. Kelsen não justifica esta sua posição ou, melhor dizendo, mera constatação decorrência lógica da Teoria Pura, muito menos esclarece sob quais condições ela se verifica, o quando e o porquê, muito provavelmente porque a aplicação do direito independe, ora, do direito (positivo) em qualquer situação.

Ora, a interpretação autêntica, aquela que cria o direito, materializa-se num ato dúplice, misto de conhecimento e vontade. Pois bem, segundo os pressupostos epistemológicos de Kelsen, a vontade estaria fora da esfera da ciência e do dever ser, pertencendo à esfera política do ser, e por esta razão não cuida dela na questão da interpretação autêntica e assim permanece fiel à sua base científica. No entanto, eis aqui o paradoxo inafastável de toda a Teoria Pura do Direito: a criação da norma inferior ou a aplicação de uma possibilidade normativa exterior à moldura jurídica esboçada pela norma superior rompe este mesmo postulado metodológico de separação entre ser e dever ser, entre ciência e política, entre a ciência jurídica e a sociologia, a religião, a ideologia, etc., e de certo modo o inverte: a questão já não é mais sobre a validade da norma (conferida pelo dever ser normativo e que independe do cumprimento ou descumprimento desta norma), mas sim sobre a eficácia da norma, pertencente ao mundo do ser, já que pela vontade o intérprete autêntico cria, de fato, direito exterior não pressuposto, independente, enfim, daquele dever ser normativo.

Por esta razão, “[...] a teoria pura do Direito, que postula a indedutibilidade do dever ser de um ser, acaba, porém, na faticidade.” (LARENZ, 1997, p. 98). Se o dever ser não pode ser deduzido do ser, ou seja, a norma não pode ser deduzida do fato (pressuposto básico do normativismo), tampouco o ser pode ser deduzido do dever ser, já que pode fugir a este. $\mathrm{O}$ vácuo então existente é criado e preenchido pela vontade do intérprete autêntico.

Sim, a aplicação jurídica passaria a ser tratada, simplesmente, como uma questão de eficácia do Direito, ou seja, da aplicação ou não das normas jurídicas, e não mais como uma questão de validade do Direito, isto é, de como a aplicação do Direito, segundo o próprio Direito, deve dar-se; uma confusão entre o nível do 'ser' e o nível do 'dever-ser' que a Teoria Pura tanto procurou evitar. (CATTONI DE OLIVEIRA, 2012, p. 142).

Kelsen cai novamente em contradição. Aliás, a rigor não há qualquer contradição no discurso da Teoria Pura, pois ele omite o problema que, no entanto, permanece latente: Se não há método capaz de extrair do dever ser normativo a resposta correta, se a resposta correta é uma ilusão e, portanto, apenas existem possibilidades normativas, como verificar estas possibilidades e como saber se de fato todas elas estão contidas na moldura? De que modo então é possível 
classificar a norma inferior produzida pela interpretação autêntica como interior ou exterior à moldura?

Todas estas perguntas fundamentais ficam sem respostas.

Kelsen apenas discorre que na interpretação autêntica, principalmente no elemento volitivo desta, adentram certamente "outras normas" de moral, justiça, etc., mas não sendo normas jurídicas, a ciência do direito positivo nada pode dizer sobre sua "validade e verificabilidade", limitando-se a admitir sua existência e influência na norma final.

Na medida em que, na aplicação da lei, para além da necessária fixação da moldura dentro da qual se tem de manter o ato a pôr, possa ter ainda lugar uma atividade cognoscitiva do órgão aplicador do Direito, não se tratará de um conhecimento do Direito positivo, mas de outras normas que, aqui, no processo da criação jurídica, podem ter a sua incidência: normas de Moral, normas de Justiça, juízos de valor sociais que costumamos designar por expressões correntes como bem comum, interesse do Estado, progresso, etc. Do ponto de vista do Direito positivo, nada se pode dizer sobre a sua validade e verificabilidade. [...] Relativamente a este, a produção do ato jurídico dentro da moldura da norma jurídica aplicanda é livre, isto é, realiza-se segundo a livre apreciação do órgão chamado a produzir o ato. (KELSEN, 2009, p. 393, grifo nosso).

Por outro lado, Kelsen constata que, em decorrência, a norma gerada pela interpretação autêntica cuja escolha se deu por alguma possibilidade normativa de fora da moldura pode, como qualquer outra, tornar-se precedente, adquirindo assim generalidade e vinculatividade se não for anulada pelo Tribunal de última instância.

Este exemplo de grandes repercussões nos oferece uma visão privilegiada tanto acerca das consequências possíveis e de fato existentes da hermenêutica da Teoria Pura, ainda mais perniciosas em países periféricos de baixa tradição democrática e constitucional, quanto de sua fragilidade perante os próprios pressupostos científicos da Teoria Pura do Direito. A doutrina hermenêutica contida na Teoria Pura, mormente a interpretação autêntica e seu elemento volitivo, “[...] é dificilmente compatível com a função da judicatura no Estado constitucional.” (LARENZ, 1997, p. 108). Como última consequência, é exatamente este elemento volitivo, a vontade, que de fato produz ou aniquila o direito, legitima-o ou deslegitima-o, indiferente a qualquer dever normativo, independentemente de qualquer teoria ou ciência.

Por esta razão o positivismo normativista de Hans Kelsen permanece tão forte. Ele traz subrepticiamente muito do que, erroneamente, considera-se como seu antídoto. Pode-se dizer que a conclusão da Teoria Pura do Direito expressa na hermenêutica jurídica do capítulo oitavo seja apenas outra forma mais sofisticada de defender os postulados do movimento do direito livre, o 
qual propunha a liberdade total do intérprete e aplicador. À hora da aplicação do direito vale tudo, os juristas estão livres.. da lei. Curiosamente uma das escolas de combate ao positivismo exegético, abrindo caminhos para o normativismo de Kelsen e que hoje apresenta força em suas variadas formas de correntes voluntaristas.

\section{CONSIDERAÇÕES FINAIS}

Immanuel Kant realiza na filosofia o que Nicolau Copérnico realizou na astronomia, aproximação notada pelo próprio filósofo de Königsberg (2001, p. 49). Se Nicolau Copérnico desconstruiu de maneira irreversível o milenar sistema ptolomaico adotado pela Igreja Católica, substituindo a Terra pelo sol como centro da ordem planetária, Kant faz a filosofia voltar-se totalmente para a mente humana, o modo de seu funcionamento, enfim, como é possível o conhecimento e como o ser humano, ser racional, conhece. Em suma, a razão humana de si para si mesma, destituída de qualquer consideração mística ou religiosa ${ }^{18}$. Eis a decisiva contribuição de ambos para o humanismo, na secularização do mundo projetada pela modernidade.

Na revolução copernicana operada por Kant, o sujeito cognoscente é o centro solar do universo racional em torno do qual giram os objetos cognitivos. Há a definitiva cisão no pensamento moderno entre sujeito e objeto, diferenciando a metafísica moderna da clássica. O conhecimento apenas é possível a partir desta separação entre o que conhece e o que é conhecido.

Somente com esta cisão entre sujeito e objeto do conhecimento torna-se possível para Hans Kelsen construir a Teoria Pura do Direito, onde cabe ao sujeito da interpretação não autêntica conhecer e descrever o objeto específico de sua ciência, a norma. Aí está a pequena grande herança de Kant para Kelsen: pequena pois, como vimos, da enorme obra kantiana Kelsen serve-se apenas da epistemologia, afastando veementemente a doutrina moral de estreitíssima conexão com o direito; grande, pois esta é a operação mais fundamental na filosofia do Ocidente desde os gregos, da qual Kelsen não poderia passar imune e também da qual a sua Teoria Pura depende. Longe de

\footnotetext{
18 "Nunca posso, portanto, nem sequer para o uso prático necessário da minha razão, admitir Deus, liberdade $e$ imortalidade, sem ao mesmo tempo recusar à razão especulativa a sua pretensão injusta a intuições transcendentes, porquanto, para as alcançar, teria necessariamente de se servir de princípios que, reportando-se de fato apenas aos objetos de experiência possível, se fossem aplicados a algo que não pode ser objeto de experiência, o converteriam realmente em fenômeno, desta sorte impossibilitando toda a extensão prática da razão pura. Tive, pois, de suprimir o saber para encontrar lugar para a crença." (KANT, 2001, p. 53).
} 
ser exclusiva, Kelsen compartilha a herança epistemológica de Kant com a própria modernidade, enfim.

Por outro lado, a Teoria Pura do Direito é toda ela, basicamente, conceitual. O discurso kelseniano constrói-se em definições e distinções entre conceitos; conceitos puros dados a priori, independentes da experiência, como a norma e a norma hipotética fundamental, residindo aí outra influência do pensamento de Kant.

O mestre de Königsberg também afirma a impossibilidade de derivar o dever ser do ser, mas qualquer aproximação com a doutrina de Kelsen neste ponto mostra-se completamente descabida. Em Kant, a lei moral comanda a ação, o dever ser é mandamento racional da moralidade (no que a doutrina de Kant deve muito a Descartes). Em suma, o dever ser refere-se a leis morais inatas à racionalidade. Já o dever ser de Kelsen, muito diferente, é simplesmente a norma com a qual se ocupa exclusivamente a Teoria Pura do Direito. De modo que, em conclusão, a semelhança está na nomenclatura e nada mais.

Despojada da doutrina ética (que compreende a moral e o direito), recusando em consequência o imperativo categórico, além de transformar decisivamente o ser e o dever ser originais, Kelsen recebe pouco de Kant.

\section{REFERÊNCIAS}

CATTONI DE OLIVEIRA, Marcelo Andrade. Teoria da constituição. Belo Horizonte: Initia Via, 2012.

FERRAZ JUNIOR, Tércio Sampaio. Introdução ao estudo do direito: técnica, decisão, dominação. 6. ed. rev. e ampl. São Paulo: Atlas, 2008.

HOFFE, Otfried. Justiça política: fundamentação de uma filosofia crítica do direito e do Estado. Trad. Ernildo Stein. 3. ed. São Paulo: Martins Fontes, 2005. (Justiça e direito).

KANT, Immanuel. Crítica da razão prática. Trad. e pref. Afonso Bertagnoli. São Paulo: Brasil S.A., 1959.

KANT, Immanuel. Crítica da razão pura. Trad. Manuela Pinto dos Santos e Alexandre Fradique Morujão. Introd. e notas: Alexandre Fradique Morujão. 5. ed. Lisboa: Fundação Calouste Gulbenkian, 2001.

KANT, Immanuel. Fundamentação da metafísica dos costumes. Trad. Paulo Quintela. Lisboa: Ed. 70, 2007. (Textos filosóficos). 
KANT, Immanuel. Metafísica dos costumes. Trad., textos adicionais e notas: Edson Bini. Bauru: EDIPRO, 2003. (Clássicos Edipro).

KANT, Immanuel. Para a paz perpétua. Estudo introd. Joám Evans Pim. Trad. Bárbara Kristensen. Rianxo: Instituto Galego de Estudos de Segurança Internacional e da Paz, 2006. (Ensaios sobre paz e conflitos; v. 1).

KELSEN, Hans. A justiça e o direito natural. Trad. e pref. João Baptista Machado. Coimbra: Livraria Almedina, 2001.

KELSEN, Hans. Jurisdição constitucional. Introd. e rev. téc. Sérgio Sérvulo da Cunha. São Paulo: Martins Fontes, 2003. (Justiça e direito).

KELSEN, Hans. O problema da justiça. Trad. João Baptista Machado. 3. ed. São Paulo: Martins Fontes, 1998.

KELSEN, Hans. Teoria pura do direito. Trad. João Baptista Machado. 8. ed. São Paulo: WMF Martins Fontes, 2009. (Biblioteca jurídica WMF).

LARENZ, Karl. Metodologia da ciência do direito. Trad. José Lamego. 3. ed. Lisboa: Fundação Calouste Gulbenkian, 1997.

MATOS, Andityas Soares de Moura Costa. A concepção de justiça em Hans Kelsen em face do positivismo relativista e do jusnaturalismo absolutista. 2004. 177 f. Dissertação (Mestrado em Direito) - Universidade Federal de Minas Gerais, Belo Horizonte, 2004. Disponível em: http://bibliotecadigital.ufmg.br/dspace/bitstream/handle/1843/BUOS-

967PD6/direito_andityassoaresmouracostamatos_disserta_o.pdf?sequence=1. Acesso em: 20 dez. 2019.

PAULSON, Stanley. A ideia central do positivismo jurídico. Trad. Thomas da Rosa de Bustamante. Rev. téc. Andityas Soares de Moura Costa Matos. Revista Brasileira de Estudos Políticos, Belo Horizonte, n. 102, p. 101-137, jan./jun. 2011.

\title{
HANS KELSEN'S KANTIAN HERITAGE ON THE PURE THEORY OF LAW
}

\begin{abstract}
The article investigates the great Kantian heritage on Hans Kelsen's Pure Theory of Law, one of the most important works of the twentieth century's legal theory. It researches the Critique of Pure Reasons' epistemology and Kant's ethical-moral doctrine told in the Critique of Practical Reason, in the Metaphysics of Morals and its Groundwork and the consequences of their adoption or refusal mainly in the legal hermeneutics, interpretation and application of law, of the Kelsenian doctrine.
\end{abstract}


Keywords: Pure Theory of Law. Morals. Categorical imperative. Legal hermeneutics. 